\title{
Det är svårt att se helheten i tekniska system
}

\author{
Emilia Fägerstam \\ Linköpings universitet
}

Kunskap om tekniska system är ett viktigt innehåll i teknikämnet. Ny forskning visar dock att blivande tekniklärare har svårt att identifiera de osynliga delarna $\mathrm{i}$ ett system. Lärarutbildningar behöver därför ha en tydlig helhetssyn i sin undervisning om tekniska system.

Kunskap om tekniska system är viktig inte bara för att tekniska system har en allt mer framträdande roll i våra dagliga liv, det behövs även för en generell förståelse för teknik. Därför behöver lärare ha god kompetens i hur system fungerar. Forskare från Linköpings universitet har undersökt tekniklärarstudenters förståelse av tekniska system [1]. De delade ut enkäter till 26 studenter vid tre olika universitet med öppna frågor om tre olika tekniska system; mobiltelefonen, hissen och elnätet.

Resultaten visade att studenternas förståelse för tekniska system kunde delas upp i tre olika kategorier; beståndsdelars struktur och funktion, flöden och samband, samt helhetssyn. Överlag hade studenterna svårt att förstå tekniska system. Deras svar var också ojämna i och med att de kunde svara utförligt när det gällde ett system men sedan lämna det mesta obesvarat när det gällde ett annat system.
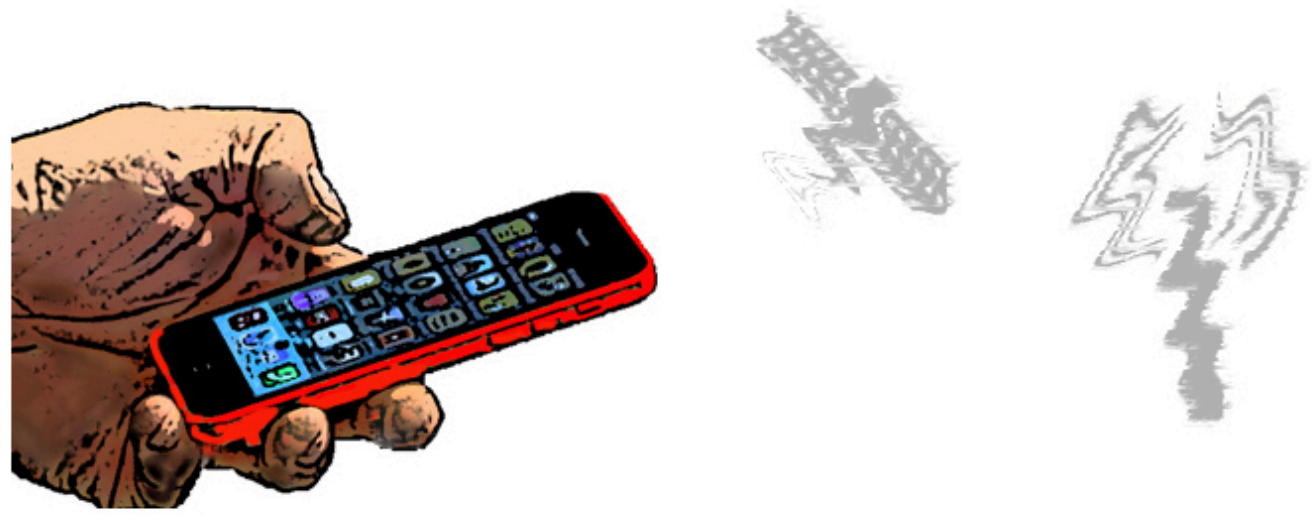

Figur 1. Resultaten visade att studenternas förståelse för tekniska system kunde delas upp i tre olika kategorier. 


\section{Fokus på systemens delar}

De flesta studenterna fokuserade på att endast beskriva synliga delar och deras funktion. Många studenter hade till exempel en god bild av hur en mobiltelefon med dess programvara fungerar. Samtidigt visade de mindre förståelse för hur telefonen är en del i ett större system av mobilt bredband, radio och satellitnavigering.

En mindre grupp studenter inkluderade systemtänkande genom beskrivningar av flöden såsom information, energi eller materia. Få studenter visade en god förståelse av kontrollmekanismer i system, till exempel i en hiss, och människans roll var ofta förbisedd. När människor nämndes som aktörer i system var det framför allt som användare men sällan som beslutsfattare, ägare eller utvecklare.

Bara några få studenter kunde beskriva systemen som en helhet och göra jämförelser mellan olika system. De beskrev också systemen i ett sammanhang där människor och miljö interagerar med tekniken.

\section{Viktigt att lärarutbildning ger helhetssyn på tekniska system}

Forskarna menar att alla tre perspektiven på system (delar, system och helhet) behövs för att förstå teknik och att de kompletterar varandra. Det är något som lärare i skolan bör vara medvetna om och lärarutbildningar behöver därför ha en tydlig helhetssyn i sin undervisning om tekniska system.

Studien bekräftar tidigare forskning som visar att tekniska system är svåra att förstå, inte bara för elever utan också för lärarstudenter. En slutsats är att tekniklärarutbildningar bör främja god undervisning om tekniska system. Särskilt fokus bör vara på hur komponenter fungerar och samverkar med varandra, flöden av information och människans roll i tekniska system.

Studenterna besvarade enkäten i början av sina studier eftersom forskarna var intresserade av deras vardagsförståelse av tekniska system. De flesta hade inriktning mot undervisning i grundskolan men en del var blivande förskollärare eller gymnasielärare. En majoritet av dem hade tidigare undervisat i teknologi.

\section{Lärarpanel}

Maria Edin från NTI-gymnasiet i Luleå tycker att artikelns innehåll var spännande och instämmer i att tekniska system är ett viktigt område. Eleverna behöver få god insikt i hur tekniska system fungerar. Artikeln bidrog också med inspiration till den egna undervisningen.

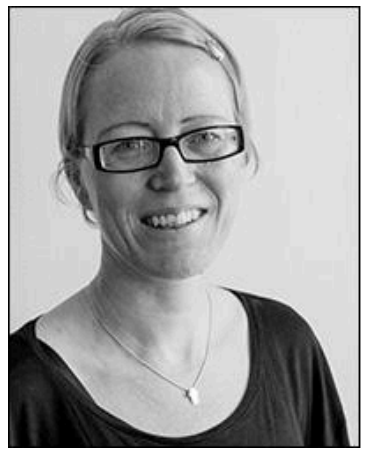

Figur 2. Maria Edin, gymnasielärare 
-Jag fick inspiration till att kanske konstruera någon uppgift om något av de tekniska system som nämns i artikeln. Mobiltelefoni är ju eleverna generellt sett intresserade av, så kanske skulle de tycka att en sådan uppgift var rolig att arbeta med.

Maria menar vidare att de områden som tas upp i artikeln skulle passa bra att jobba med för att täcka in kunskapskravet om att lösa tekniska problem, läsa ritningar, använda tekniska begrepp och genomföra beräkningar.

En sak Maria funderar över är valet att undersöka studenternas förståelse innan utbildningen.

-Det är klart att deras helhetssyn då inte är så stor. Det är väl det de ska lära sig under utbildningens gång?

Hon tycker att det hade varit mer värdefullt att se hur lärarstudenterna såg på tekniska system efter sin utbildning, eller kanske både före och efter, eftersom man då hade kunnat uttala sig om hur lärarutbildningen uppfyller dessa krav.

Maria undervisar i matematik, kemi och teknik vid NTI-gymnasiet i Luleå.

\section{Notering}

Denna text har tidigare publicerats på Linköpings universitets hemsida.

\section{Referenser}

1. Hallström J, Klasander C. Visible parts, invisible whole: Swedish technology student teachers' conceptions about technological systems. International Journal of Technology and Design Education. 2017;27:387-405. 